\title{
A Genre and Multimodal Analysis of Milk Formula Advertisements in a Local Parenting Magazine
}

\author{
Lee Yong Yong \\ Politeknik Sultan Abdul Aziz Shah, Malaysia \\ Cecilia Cheong Yin Mei \\ Department of English Language, Faculty of Languages \& Linguistics, Universiti Malaya, Malaysia
}

Submitted: 18/11/2018. Revised edition: 11/12/2018. Accepted: 18/12/2018. Published online: 18/12/2018

\begin{abstract}
The interplay of language and images is no longer uncommon in advertisements. This is particularly true for milk formula advertisements. Strategically used and effectively applied, these elements can persuade readers and create awareness in them of the certain brand and product. In this book chapter, the communicative purposes and rhetorical structure of milk formula advertisements will be presented. This is also followed by the strategies used on the multimodal features where the compositional meaning metafunction in shaping the milk formula advertisements will be discussed.
\end{abstract}

Keywords: Genre analysis, milk formula, advertisements, multimodal analysis

\section{INTRODUCTION}

\section{Advertising and Milk Formula Sales}

Advertisements are wonderful examples to illustrate the diverse roles we fulfill and engage in the society we live in. This can be very enlightening especially in seeing how people communicate, connect and relate to each other in various communicative acts and activities performed. As important as the role that advertising plays in our everyday lives, nobody truly escapes the superior power of advertisements. Our habits, exposures, and thoughts are deeply intertwined in what we perceive from the advertisements so much so that they form the basis of our decisions and opinion. How often do we watch a Milo advertisement and believe it is the healthiest nutrition drink? How often do we run to the store for Milkmaid condensed milk believing it is still the best? And how often do we purchase the particular brand repetitively based on its advertisement? Likewise, in milk formula advertisements, parents rely on what is often advertised to make their feeding decisions especially for their growing up

*Correspondence to: Cecilia Cheong Yin Mei (email: ceciliac@um.edu.my) 
children. While they may often receive feeding advices from their paediatricians, medical experts and professionals, most parents fall back on the information, testimonials, and recommendations, advertised.

As for milk formula advertisements, the milk formula industry itself has nearly USD $\$ 50$ billion dollar market in the world (Nielsen, 2015). In Malaysia alone, the European Research Council's extensive market research states that the Malaysian baby food market is dominated by baby milk products which account for $90.1 \%$ of retail sales (Acute Markets Report, 2015). As this sector is supported by "a very large number of brands, among which premium and super premium products have been performing particularly well", the companies often compete to effectively promote their products to potential consumers. According to Business News Report in The Star (January 26, 2016), the total advertising expenditure for Malaysia in 2015 was RM13.63 billion where growing up milk for children ranked fifth among other products and services in Malaysia as further illustrated in Table 1.

Table 1 Top five product/ service categories in Malaysia based on advertising expenditure in 2015 (The Star, 2016)

\begin{tabular}{|l|l|}
\hline Ranking & Product and Service Categories \\
\hline 1 & Local government institutions \\
\hline 2 & Women's facial care \\
\hline 3 & Mobile line services \\
\hline 4 & Hair shampoo and conditioner \\
\hline $\mathbf{5}$ & Growing-up milk for children \\
\hline
\end{tabular}

The growth in growing-up milk advertising expenditures is justifiable along with the worldwide decline of breastfeeding rates where only $43 \%$ of babies were reportedly to be exclusively breastfed for six months globally (UNICEF, 2016). According to Canadean's Market Research report in 2015, around 29,375 tonnes of baby milk were consumed in 2014. Birth rates were reported to have declined by $4 \%$ between 2011 and 2014 and this is to deteriorate further by $6 \%$ in 2020 . As a result, the number of infants will be lower, while the number of toddlers aged between 1 and 3 will increase. This change will have a significant effect on the market as a whole, with specialized and follow-on milks increasing their market share in the next few years. Milk suppliers are likely to focus on products for older children, and try to expand the $3+$ and 6+ years markets (Canadean, 2017). With more competitive milk formula market, how then will the advertisers come about in advertising their products? What would be the strategies employed in order to compete and sell their milk formula? The following figure illustrates the top five companies in the global milk formula industry. 


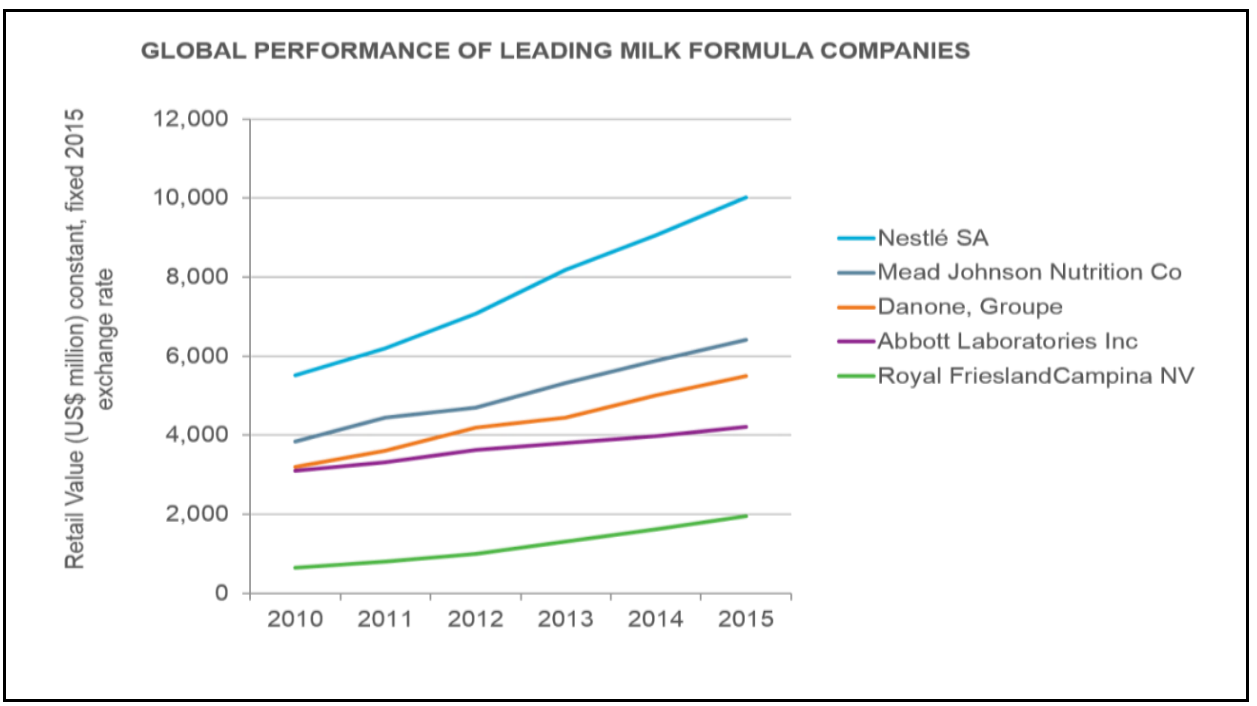

Figure 1 Global Performance of Leading Milk Formula Companies

\section{Communicative Purposes of Milk Formula Advertisements}

Milk formula advertisements are generally created to fulfill specific communicative purposes in order to reach out to the audience. To begin with, it is vital to truly examine the specific communicative purposes of milk formula advertisements in order to find out why they are created and advertised. In order to do so, 35 milk formula advertisements from a local parenting magazine have been selected. The communicative purposes were identified based on each move applied by the advertisers to advertise their products. This is done by using Bhatia's (1993) model of genre analysis where he identified four main communicative purposes of sales promotion as a framework. The four communicative purposes identified are further explained in the following table.

Table 2 Bhatia's (1993) Model of Communicative Purposes

\begin{tabular}{|c|l|}
\hline Communicative Purpose & Explanations \\
\hline a. To persuade & $\begin{array}{l}\text { Main function of sales promotion letters in order to draw upon the } \\
\text { desired response. }\end{array}$ \\
\hline b. To capture attention & $\begin{array}{l}\text { Sustaining consumers interest even when they may not display } \\
\text { immediate need. }\end{array}$ \\
\hline c. To offer appraisal & $\begin{array}{l}\text { Further detailed information provided to address the interest, need } \\
\text { or inhibitions of consumers. }\end{array}$ \\
\hline d. To encourage further & $\begin{array}{l}\text { Business communication initiated between seller and potential } \\
\text { buyers. }\end{array}$ \\
\hline
\end{tabular}


Based on Bhatia's (1993) analytical framework, the findings show that milk formula advertisements cover all the four communicative purposes proposed albeit in various degree of importance. Figure 1 displays the communicative purposes of milk formula advertisements.

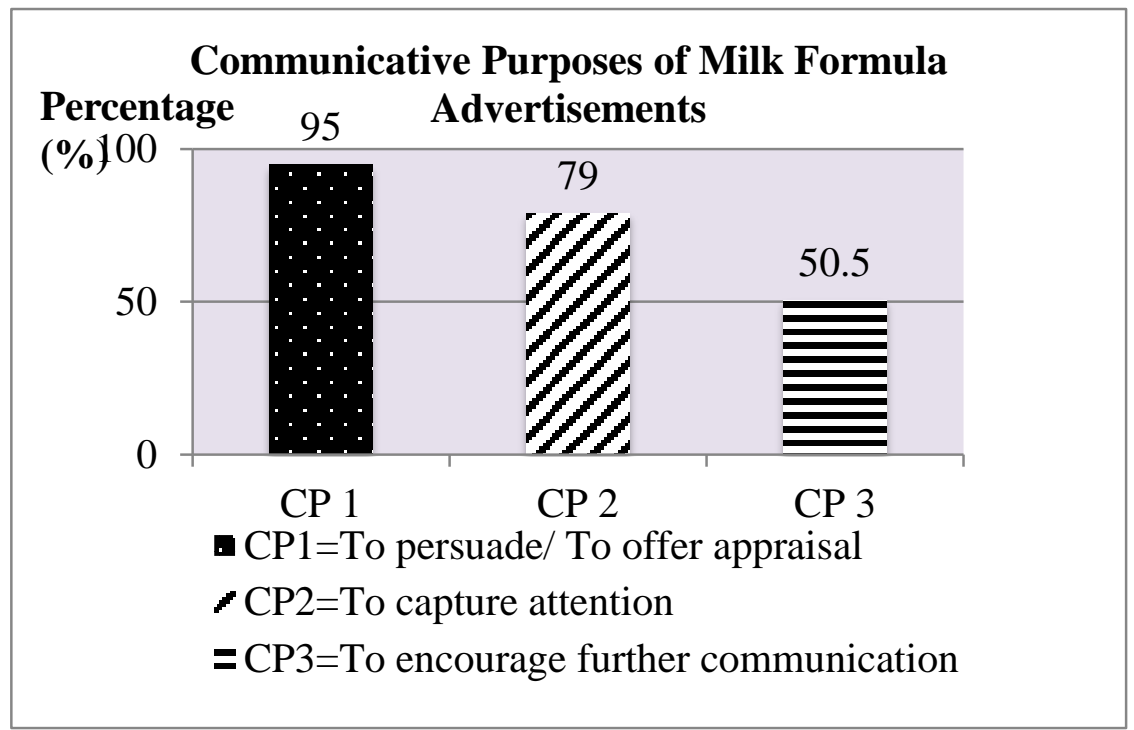

Figure 2 Communicative Purposes of Milk Formula Advertisements

Based on the figure, the main communicative purpose of milk formula advertisements is to persuade or to offer appraisal $(95 \%)$ to consumers. This is followed by its purpose to capture the reader's attention $(79 \%)$, and lastly to encourage further communication $(50.5 \%)$ between potential consumers and milk formula companies. Advertisers used various strategies such as justifying the products, providing product details and information, incorporating footnote for additional information and references, and citing research findings to persuade or to offer appraisal about their milk formula products. In persuading the consumers, the credentials of the milk formula companies are also established by providing company information and achievements. The examples are shown in the following.

Every day, you can also boost your picky eater's nutritional status with PediaSure, the only 100\% nutritionally complete formula that is scientifically shown to improve the growth of picky eaters.

(Advertisement 26) 
In the above example, the advertisers indicated the advantages of the milk formula product by assuring that the formula is scientifically proven and is $100 \%$ nutritionally complete (Move 10). The advertisers tried to persuade the consumers by reasoning with them using scientific information and nutrition assurance. With that, advertisers also appraised their milk formula product by telling the consumers what their child needs on a daily basis (Move 3). These moves are examples used by advertisers to achieve the communicative purpose of persuading and offering appraisal.

Experiences create unforgettable memories, foster togetherness and most importantly, help your child learn. But only when your child is strong from the inside, can he readily and wholeheartedly embrace these new experiences together with you.

Friso Gold, through our unique Single Manufacturing Process, takes the natural goodness of fresh milk from our farm in Holland and seals it into every glass, to make your child stronger from the inside. This is so that you and your child can say Yes to experiencing everything the outside world has to offer together.

(Advertisement 29)

In this example, the emotions of the consumers are tapped through the concept of 'experience'. Consumers are made to engage in the idea of "doing things together with their child in the outside world' fashionably. The persuasion is further intensified through the introduction of the product by stating where the fresh milk is imported, hence implying superiority and added advantage. The product is appraised by detailing how the milk is produced. This whole new level of experience takes consumers to a different level of visualization and experience in order for them to be fully persuaded by the advertisers. This agrees with Cook's (1992) notion of 'tickle' where advertisements appeal to the emotions and mood of the consumers.

For the second communicative purpose of capturing attention, this intention is realised through three different moves; providing headlines, targeting the market and offering testimonials. To achieve this purpose, advertisers employed eye-catching and appealing taglines such as in the following examples provided.

Her Smile Says It All. (Advertisement 1)

For an Outstanding Performance in Every Way. (Advertisement 9)

When Your Child Can't Drink Cow's Milk. (Advertisement 12)

$360^{\circ}$ Development. Happy Tummies.

Formulated for delicate tummies. (Advertisement 13)

Now you can give your child a TOTAL FORMULA for his all-round growth. (Advertisement 27)

Enjoy the incredible journey. (Advertisement 30)

Smart Kids Ask Why

Why don't I float when I Jump?

Why don't things float away into outer space?

Why do they always come back down? (Advertisement 22) 
These attention-grabbing headlines address the needs of the targeted market besides offering them a solution to problems like cow's milk allergy, delicate tummies, and so on. Advertisers also engaged in "You" language in order to capture the consumer's attention. The use of second language reference is powerful enough to captivate the readers as connection is formed. Not only that, rhetorical questions are also used to strengthen the persuasive effect once the consumer's attention is captured. This may strengthen the processing of the message content in the advertisement. Some headlines may also contain the element of surprise, for example in Advertisement 22. Besides drawing the consumer's attention to read further, the advertisers sometimes include testimonials by mothers and celebrities. These testimonials are often told in a story-like manner. Through this form of communication, trust is built as stories provide context and meaning besides deepening understanding. Consumer's attention can be further held and sustained this way.

The third communicative purpose of encouraging further communication is realised by offering incentives, urging action and also soliciting response through company contact information provided. All these moves are intended to develop more connection with the consumers besides building positive image about the brand and also the company. By disclosing more information about the company, trust can also be built. Not only that, these moves used can also facilitate the consumers to commit to the product as they can contact the company for more information. Examples of these moves used to realise the communicative purpose can be seen in the following examples.

Contact us for more information or free samples at 1800883122 or visit www.facebook/AnmumClub.

(Advertisement 21)

Mom \& Baby Expo 2015.

Date $\quad: 15-17^{\text {th }}$ May 2015

Venue : Mid Valley Convention Centre

Time : 10:00-8:00 pm (Advertisement 16)

For more information, please call

1-800-88-6233

(Mon to Fri, 9.00am to 6.00pm)

Or log on to www.isomilplus.com.my (Advertisement 10)

"Genres constitute all communicative actions" (Bawarshi, 2000, p.336). Based on Bhatia's (1993) analytical framework, it has been found that milk formula advertisements cover all the four communicative purposes proposed. The main communicative purpose for milk formula advertisements is to offer appraisals and persuade. This is followed by capturing attention and lastly, to encourage further communication with the targeted audience. 


\section{Rhetorical Structure of Milk Formula Advertisements}

The rhetorical structure of milk formula advertisements is identified using Kathpalia's (1992) framework. Kathpalia (1992) found nine main moves for the promotional genre along with sub-moves or steps identified in her model and this can be further explained in Table 3.

Table 3 Rhetorical structure of a typical advertisement (Kathpalia, 1992)

\begin{tabular}{|c|c|}
\hline Moves & Explanations \\
\hline 1. Headlines & $\begin{array}{l}\text { To attract and capture reader's attention. } \\
\text { A lead to read further the body of the advertisements. }\end{array}$ \\
\hline 2. $\quad$ Targeting the market & $\begin{array}{l}\text { Targets the potential users of the product. } \\
\text { Narrows down to a smaller and more focused market. }\end{array}$ \\
\hline $\begin{array}{l}\text { 3. Justifying the product } \\
\text { - Indicating the importance or } \\
\text { need of the product or service } \\
\text { and/or } \\
\text { - Establishing a niche }\end{array}$ & $\begin{array}{l}\text { Prepares the ground for advertisements. } \\
\text { Persuades potential consumers that a particular product is } \\
\text { important. } \\
\text { Establishes a need in the readers. }\end{array}$ \\
\hline $\begin{array}{l}\text { 4. Appraising the product } \\
\text { - Identifying the product or } \\
\text { service } \\
\text { - Describing the product or } \\
\text { service } \\
\text { - Indicating the value of the } \\
\text { product or service }\end{array}$ & $\begin{array}{l}\text { Main purpose is to introduce the product to the audience. } \\
\text { Identifies the product by telling the target customers what is being } \\
\text { sold. } \\
\text { Describes the features of the product } \\
\text { Indicates the value of the product. }\end{array}$ \\
\hline 5. $\quad$ Establishing credentials & $\begin{array}{l}\text { Raises the faith and confidence of customers in the product. } \\
\text { Often manifested in the presentation of brand name, mentioning of } \\
\text { company's reputations, and also highlighting achievement and } \\
\text { awards related to the products advertised. }\end{array}$ \\
\hline $\begin{array}{llll}6 . & \begin{array}{l}\text { Celebrity / Typical user } \\
\text { endorsement }\end{array} & & \end{array}$ & $\begin{array}{l}\text { Helps to raise customer's confidence by presenting comments and } \\
\text { testimonials. } \\
\text { Can be achieved in four ways: Presenting testimonials of acclaimed } \\
\text { authorities, public or official citation of achievements, testimonies } \\
\text { of average customers, and testimonies of fictional consumers. }\end{array}$ \\
\hline 7. $\quad$ Offering incentives & $\begin{array}{l}\text { Makes purchase more appealing. } \\
\text { Discounts, free gift samples, lucky draw, etc. }\end{array}$ \\
\hline 8. $\quad$ Using pressure tactics & $\begin{array}{l}\text { Exert constraints on the advertised product simply to urge and } \\
\text { hasten buying decision. }\end{array}$ \\
\hline 9. $\quad$ Soliciting response & $\begin{array}{l}\text { Urge potential customers to take prompt and specific action in } \\
\text { order to settle or seal the deal. }\end{array}$ \\
\hline
\end{tabular}

Based on all the moves identified in the milk formula advertisements, several moves such as 'Providing footnote or reference' along with the sub-moves such as 'Presenting statistical data', 'By offering additional content and information', 'By offering citation and research findings', 'By 
disclaiming' and 'By stating terms and conditions' have been found in milk formula advertisements, hence added into the framework. The analytical frameworks from Kathpalia's (1992) work and milk formula advertisements are shown in Table 4.

Table 4 Analytical frameworks for promotional genre

\begin{tabular}{|c|c|c|c|}
\hline No. & Description of Moves & Kathpalia (1992) & Milk formula ads \\
\hline 1. & Attracting attention (Headlines) & Move 1 & Move 1 \\
\hline 2. & Targeting the market & Move 2 & Move 2 \\
\hline 3. & $\begin{array}{l}\text { Justifying the product or service } \\
\text { (Step 1) By indicating the importance or } \\
\text { need of the product or service and/ or } \\
\text { (Step 2) By establishing a niche } \\
\text { (Step 3) By presenting statistical data }\end{array}$ & $\begin{array}{l}\text { Move } 3 \\
\text { Sub-move } 3(\mathrm{a}) \\
\text { Sub-move } 3(\mathrm{~b}) \\
\text { Sub-move } 3(\mathrm{c})\end{array}$ & $\begin{array}{l}\text { Move } 3 \\
\text { Move } 3 \text { Step } 1 \\
\text { Move } 3 \text { Step } 2 \\
\text { Move } 3 \text { Step } 3\end{array}$ \\
\hline 4. & $\begin{array}{l}\text { Detailing the product or service } \\
\text { (Step 1) By identifying the product or } \\
\text { service } \\
\text { (Step 2) By describing the product or } \\
\text { service } \\
\text { (Step 3) By indicating the value of the } \\
\text { product or service }\end{array}$ & $\begin{array}{l}\text { Move } 4 \\
\text { Sub-move } 4(a) \\
\text { Sub-move } 4(b) \\
\text { Sub-move } 4(\mathrm{c})\end{array}$ & $\begin{array}{l}\text { Move } 4 \\
\text { Move } 4 \text { Step } 1 \\
\text { Move } 4 \text { Step } 2 \\
\text { Move 4 Step } 3\end{array}$ \\
\hline 5. & Establishing credentials & Move 5 & Move 5 \\
\hline 6. & $\begin{array}{l}\text { Providing celebrity or typical user } \\
\text { endorsement }\end{array}$ & Move 6 & Move 6 \\
\hline 7. & Offering incentives & Move 7 & Move 7 \\
\hline 8. & Using pressure tactics & Move 8 & Move 8 \\
\hline 9. & Soliciting response & Move 9 & Move 9 \\
\hline 10. & $\begin{array}{l}\text { Providing footnote/ reference } \\
\text { (Step 1) By offering additional content and } \\
\text { information } \\
\text { (Step 2) By providing citation and } \\
\text { research findings } \\
\text { (Step 3) By disclaiming } \\
\text { (Step 4) By stating terms and condition }\end{array}$ & & $\begin{array}{l}\text { Move } 10 \\
\text { Move } 10 \text { Step } 1 \\
\text { Move } 10 \text { Step } 2 \\
\text { Move } 10 \text { Step } 3 \\
\text { Move } 10 \text { Step } 4\end{array}$ \\
\hline
\end{tabular}

From all the ten moves identified for milk formula advertisements, eight moves have been found to be obligatory while the other two, optional. The obligatory moves are attracting attention, targeting the market, justifying the product, detailing the product, establishing credentials, soliciting response and providing footnote/ reference. The optional moves are providing celebrity or typical user endorsement, offering incentives, and urging action. These moves are presented in Table 5. 
Table 5 Obligatory and optional moves which make up the rhetorical structure of milk formula advertisements

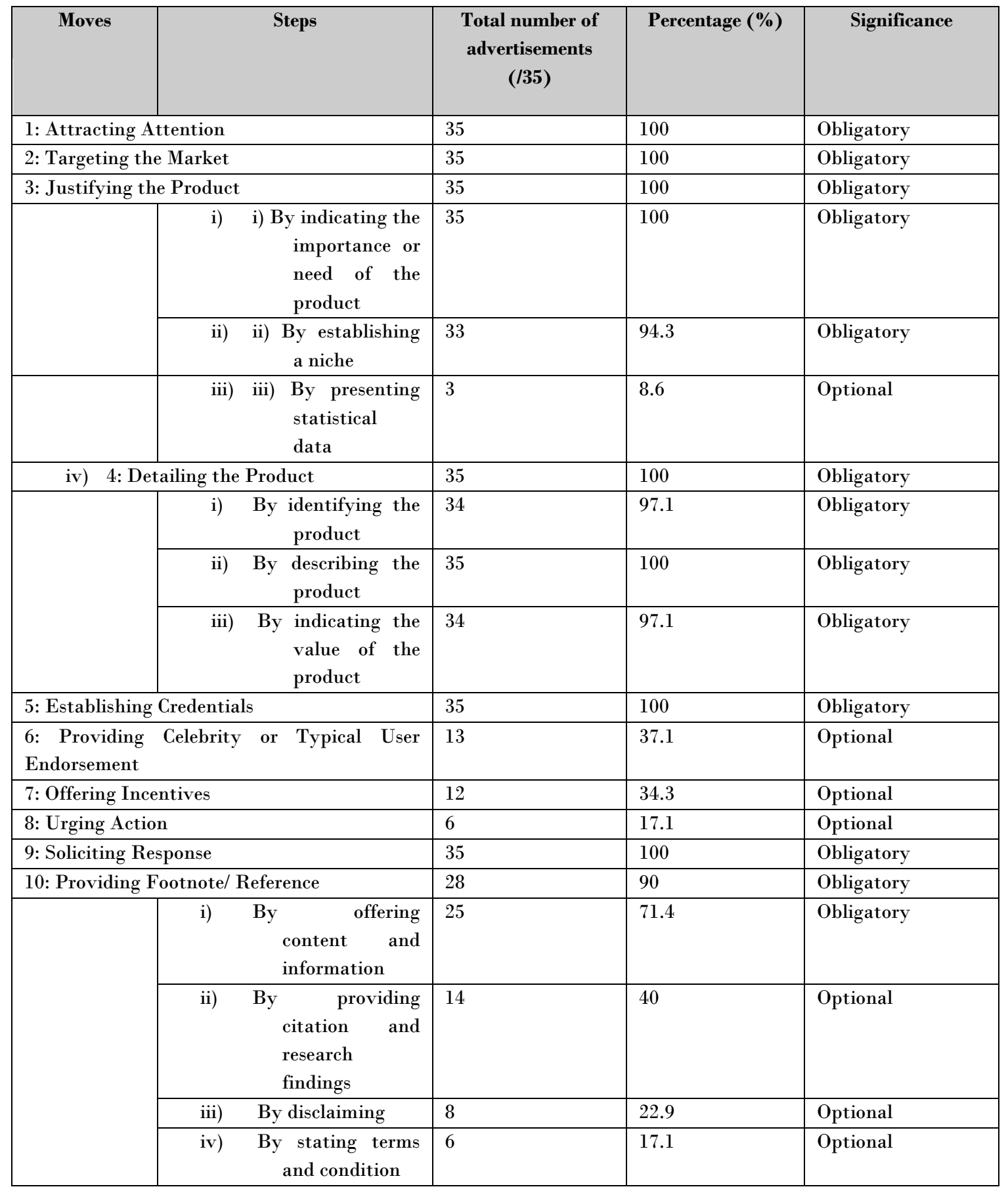


This table clearly shows that while all the nine moves as found by Kathpalia (1992) are applied in milk formula advertisements, one new move and four sub-moves were found. This demonstrates the diversity and assortment of strategies which were applied in milk formula advertisements. With that, it can be said that advertisements are fluid. The strategies applied in the past may not necessarily be the only strategies applied in the present. As advertisements continuously evolve to tap the changing needs of its consumers and the market, it is therefore vitally valid to unremittingly examine what advertisers are doing to communicate to their potential consumers.

\section{The Multimodal Features in Terms of Compositional Meaning in Milk Formula Advertisements}

Multimodality or Multimodal Analysis provides the tools and techniques to analyse texts with different semiotic resources such as images, colours, frames, etc. Van Leeuwen (2005) defined multimodality as "the combination of different semiotic modes- for example, language and music- in a communicative artefact or event" (p.28). Baldry and Thibault (2006) made the similar assertion by stating that in creating text-specific meaning, different semiotic resource systems are cocontextualized. Here, the semiotic modes are deployed simultaneously with text in order to bring about the meaning as meanings are never made with language alone.

According to Kress and van Leeuwen (1996), composition of images lies in the interaction of three interrelated systems; information value, salience and framing. These three interrelated systems are further explained in Table 6.

Table 6 The three metafunctions of two different frameworks

\begin{tabular}{|c|l|}
\hline System & Characteristics \\
\hline Information value & $\begin{array}{l}\text { The placement of elements (participants and syntagms that relate them to } \\
\text { each other and to the viewer) endows them with the specific informational } \\
\text { values attached to the various 'zones' of the image: left and right, top and } \\
\text { bottom, centre and margin. }\end{array}$ \\
\hline Salience & $\begin{array}{l}\text { The elements (participants and representational and interactive syntagms) are } \\
\text { made to attract the viewer's attention to different degrees, as realised by such } \\
\text { factors as placement in the foreground or background, relative size, contracts } \\
\text { in tonal value (or colour), differences in sharpness, etc. }\end{array}$ \\
\hline Framing & $\begin{array}{l}\text { The presence or absence of framing devices (realised by elements which create } \\
\text { dividing lines, or by actual frame lines) disconnects or connects elements of } \\
\text { the image, signifying that they belong or do not belong together in some } \\
\text { sense. }\end{array}$ \\
\hline
\end{tabular}

Based on this framework, the compositional meaning of milk formula advertisements will be discussed under the headings of information value, salience and framing to provide a glimpse into how the multimodal features are composed in milk formula advertisements. 


\section{Information Value}

Information value refers to how elements and images are placed together in order to deliver a particular value. The value of these elements may change as they are dependent on where it is located; top, bottom, left, right or centre. For instance, in an advertisement, the elements which are placed on the left hand side are considered 'given' information where readers are assumed to have already known while the right hand side information are considered 'new'. For new information, they carry the information which readers might want to know further as they are new. On the other hand, the elements which are placed on the top are considered 'ideal' while information placed at the bottom are considered 'real'. An example of this principle is shown in the following advertisement.

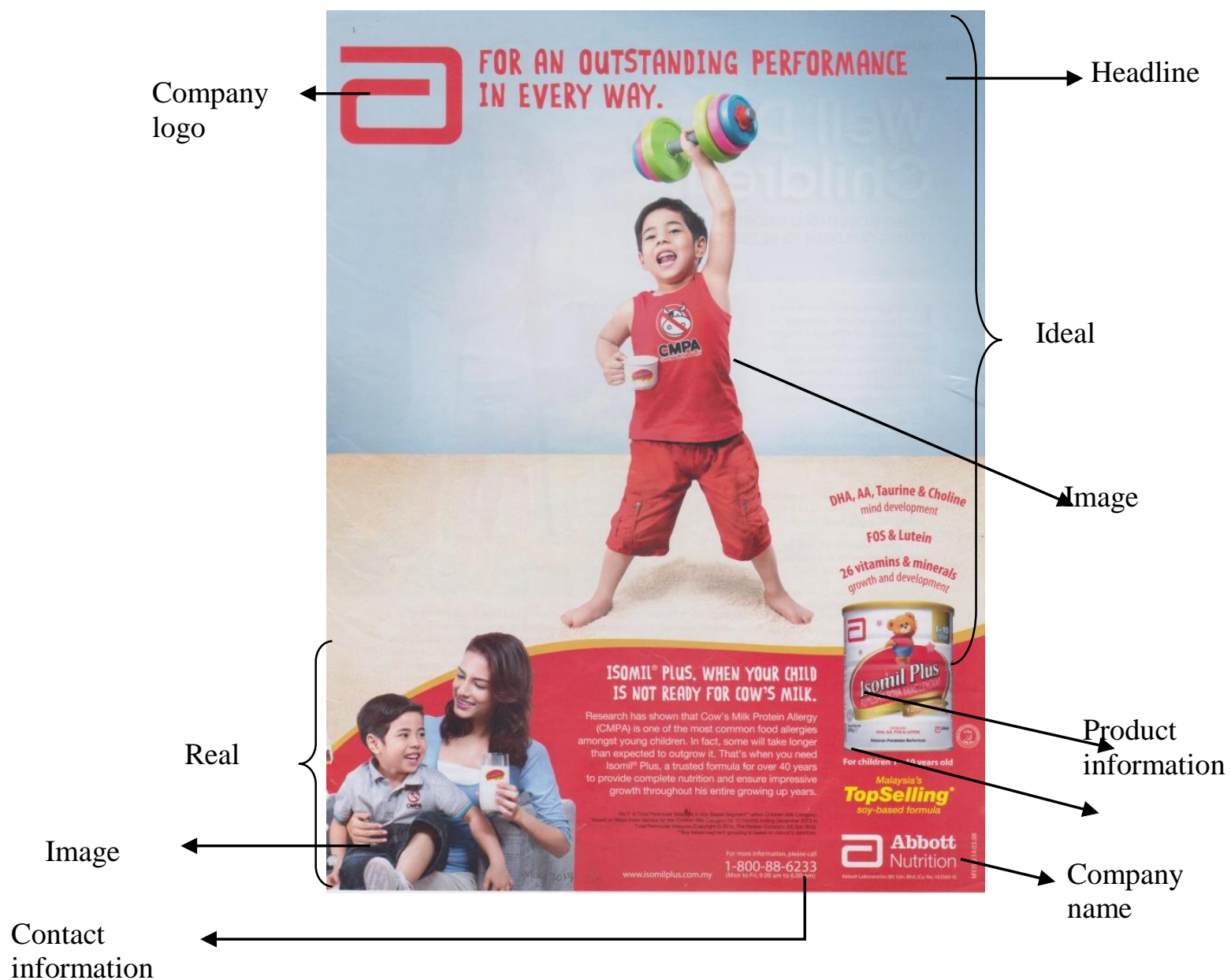

Figure 3 An example of information value for vertical layout 
From all the 35 milk formula advertisements analysed, it can be seen that the most preferred layout is the vertical layout where information is placed based on the top-bottom principle. The following table displays the results of the information value most commonly exercised by advertisers.

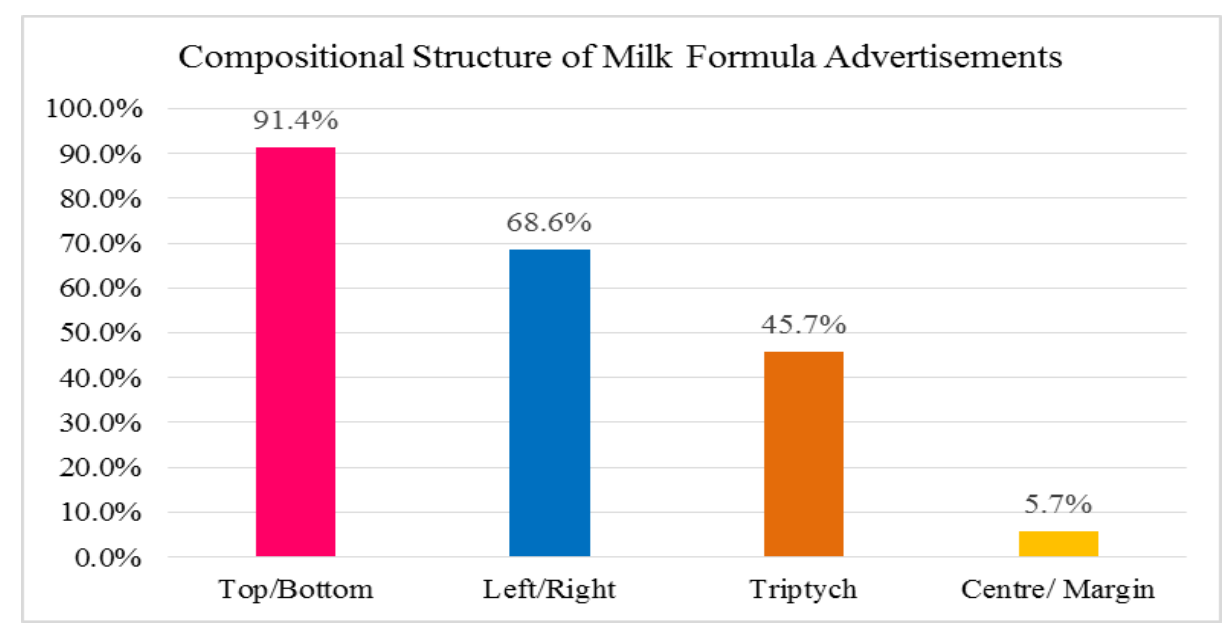

Figure 4 Compositional Structure of Milk Formula Advertisements

From Figure 4, it can be seen that the vertical layout is the most preferred compositional structure $(91.4 \%)$ for milk formula advertisements. The type of information presented in the top section appeals to the consumer's emotions and fancies exposing 'what is ideal' while the bottom section represents the factual information respectively. 32 out of 35 milk formula advertisements are built based on this structure. An example of this can be seen from the following advertisement.

Top section appeals to the emotions and fancies of the consumers

Bottom section reveals the factual information

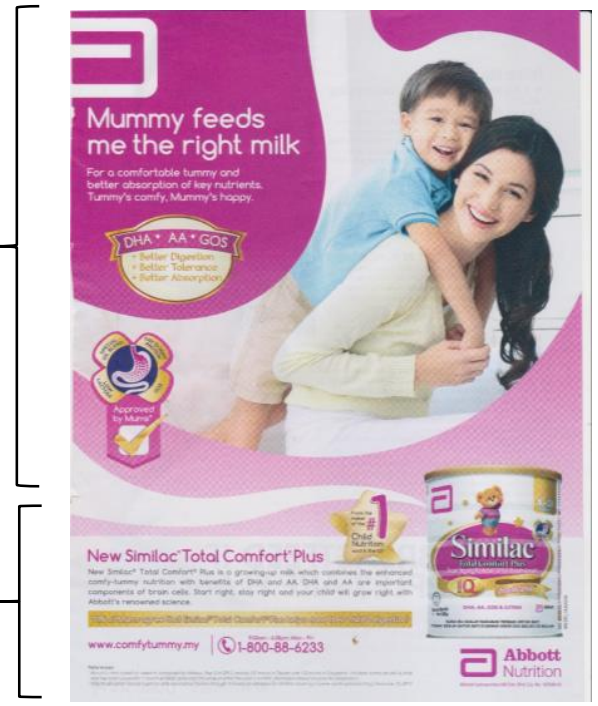

Figure 5 Example of top and bottom compositional structure in Advertisement 34 
On the other hand, the left and right layout is found in 24 of the milk formula advertisements. This contributes to $68.6 \%$ of the total score. The left section of the page carries the value of 'given' information whereas the right section carries the value of 'new' information. The left section of the page comprises information that are known or familiar. Examples of information on the left section comprises product value, new features of the product and company achievement. $45.7 \%$ of the milk formula advertisements used the triptych layout while $5.7 \%$ of the advertisements exercised the centre and margin layout.

Table 7 Type of information for the top and bottom structure

\begin{tabular}{|l|l|}
\hline Section & Type of information \\
\hline Top (Ideal) & Company logo and/or slogan \\
& Headlines \\
& Justifications of the product \\
& Image \\
& Incentives \\
\hline Bottom (Real) & Justifications of the product \\
& Picture of the product \\
& Company logo \\
& Company achievement \\
& Product description \\
\hline
\end{tabular}

\section{Salience}

Salience refers to attention-grabbing elements which usually comprise of placement in the foreground or background, sharpness in focus, colour contrast, relative size and so on. Based on the analysis, salience is realised through the use of images in large size most often placed in the foreground. These images occupy the biggest space in the advertisement. They are also comparatively larger than other elements such as signature, headlines, and product information, hence drawing reader's immediate attention. Not only that, these images also mostly dominate the top section of the advertisement hence making them ideal. The images used are mostly pictures of healthy looking children engaged in activities such as milk drinking, running, weight lifting, reading, drawing, jumping, experimenting, or exploring outdoor activities.

Besides that, salience is also realised through the use of headlines which are exercised in larger and bold fonts. The fonts used are mostly sans serif where simple lines with no embellishments are chosen. According to Hunt (2013), sans serif fonts are normally perceived as clean, modern, objective, stable and more reliable. These fonts are used by brands like Snow, Abbott, Mead Johnson, Karihome and Dumex Mamil. Friso Gold gets bolder by exercising display fonts in their advertisements. Display fonts are very enticing as it creates a certain mood in readers. This is exceptionally true for Friso Gold as the advertisements mainly focus in bringing out themes like 'experience' and 'exploration'. On the other hand, Wyeth Nutrition uses bitmap fonts for their headline in S-26 advertisement. Bitmap fonts 
are pixelated and the reason to why they have exercised this type of font is mainly to bring out the message of 'observation' in their advertisement.

Advertisements with Sans Serif Fonts Headlines

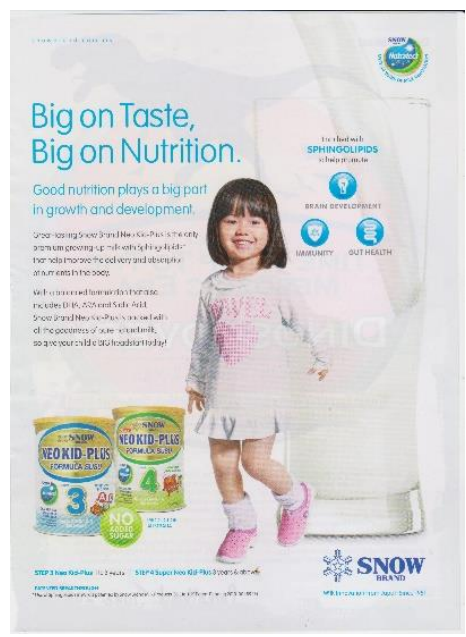

Advertisement 7

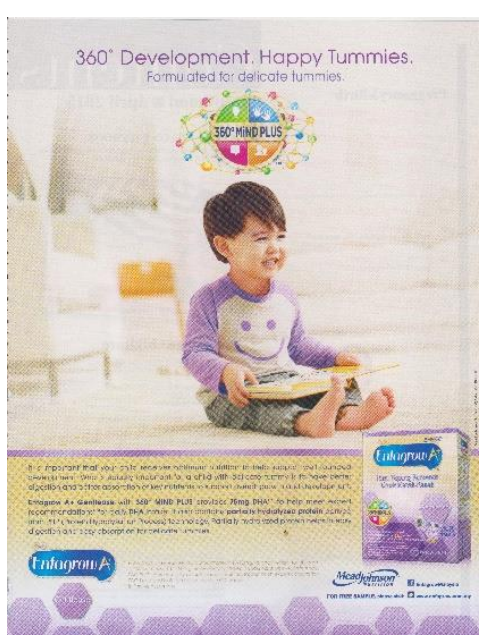

Advertisement 13

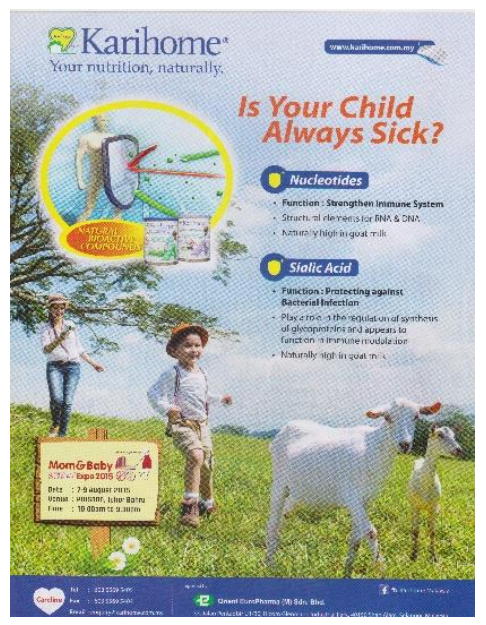

Advertisement 16

Advertisement with display fonts

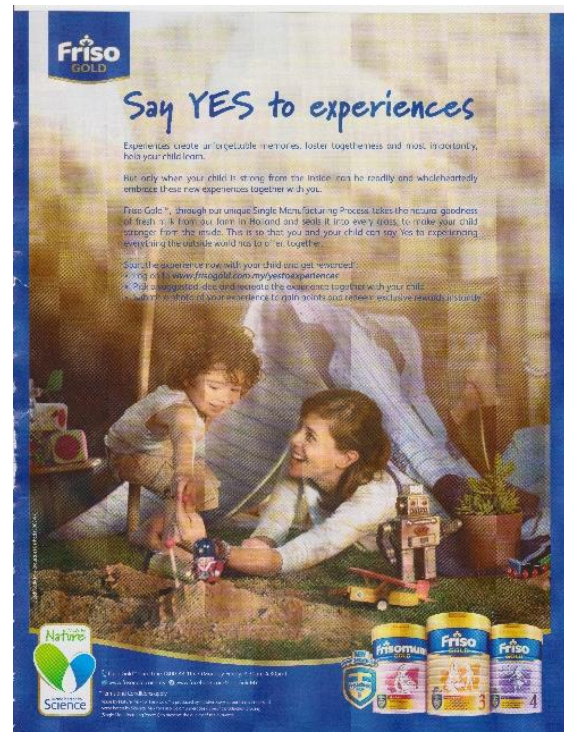

Advertisement 29 
Advertisement with bitmap fonts

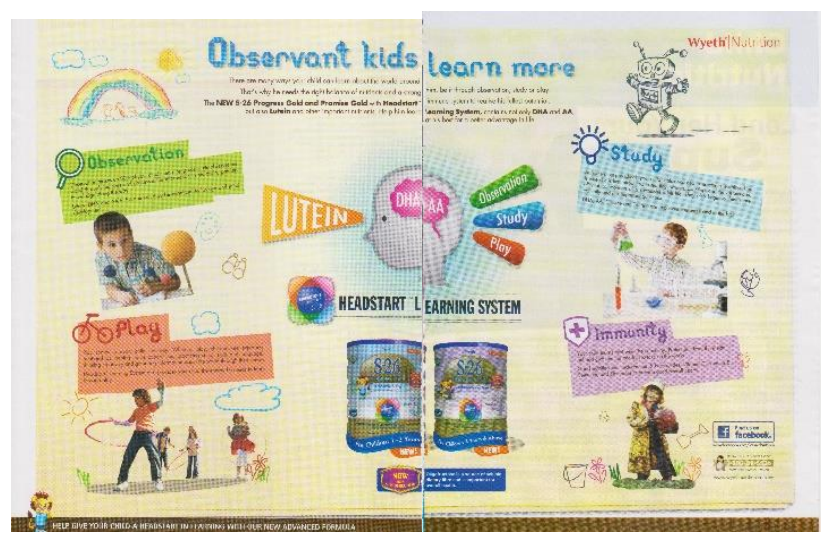

Advertisement 35

Lastly, salience is also prevalent in the choice of colour used in the advertisements. SNOW brand Neo-Kid Plus milk formula exercises white background and blue foreground, while Abbott brand Isomil Plus milk formula applies red to bring out the prominent elements. Anmum Essential uses light purple while Pediasure works with dark purple. Dumex Mamil uses red while Friso Gold maximizes the blue and gold colour. Nestle uses yellow, while Similac uses pink. Lastly, S-26 by Wyeth nutrition uses light yellow as their background.

\section{Framing}

Framing refers to the availability of framing devices such as dividing lines or actual frame lines to portray the connectivity of elements in the advertisements. From the analysis, it has been found that all 30 advertisements adopted colour contrast in framing the group of entities together while the remaining five advertisements used dividing lines. The ideal and real information are communicated and divided clearly. This technique used is effective in drawing the readers' attention to the subject of the image by guiding the eye to what's first important. 
Example of advertisements which adopted colour contrast in framing

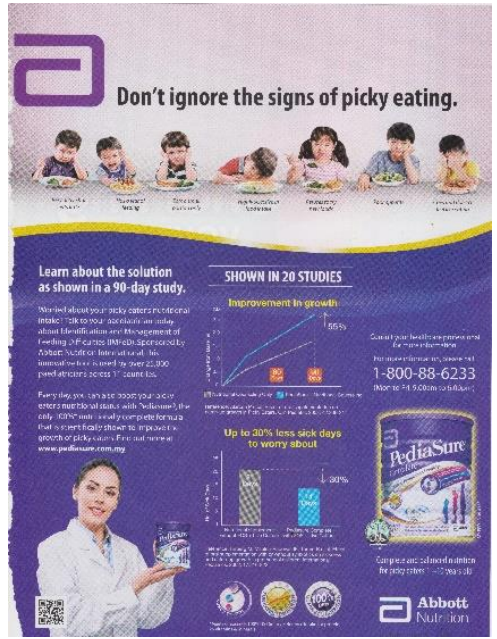

Advertisement 25

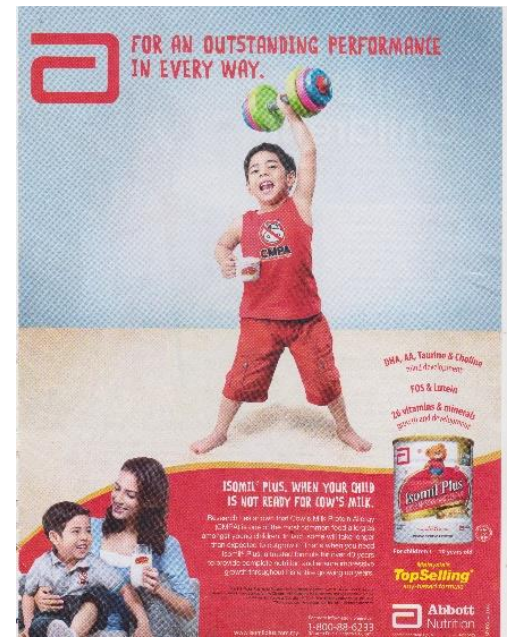

Advertisement 9

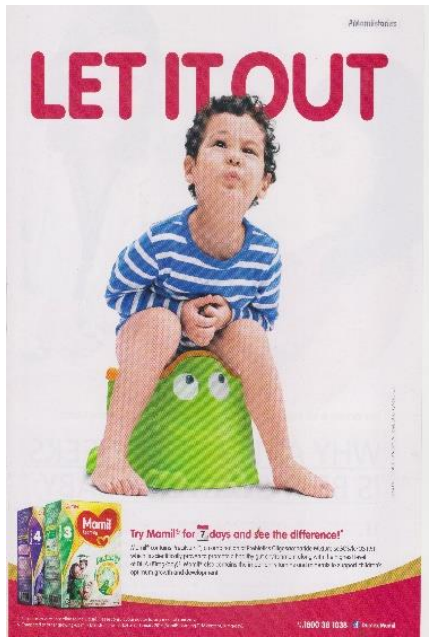

Advertisement 28

As most salience is found in the top (ideal) section of the advertisement, this framing seems to suggest its relevance. Readers' attention are first drawn toward the promise of the product before leading them to the actual product.

Example of advertisements which adopted lines in framing

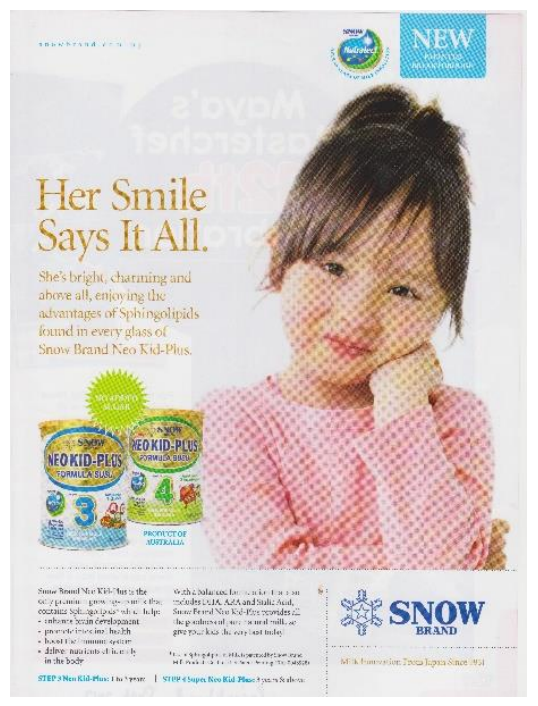

Advertisement 2

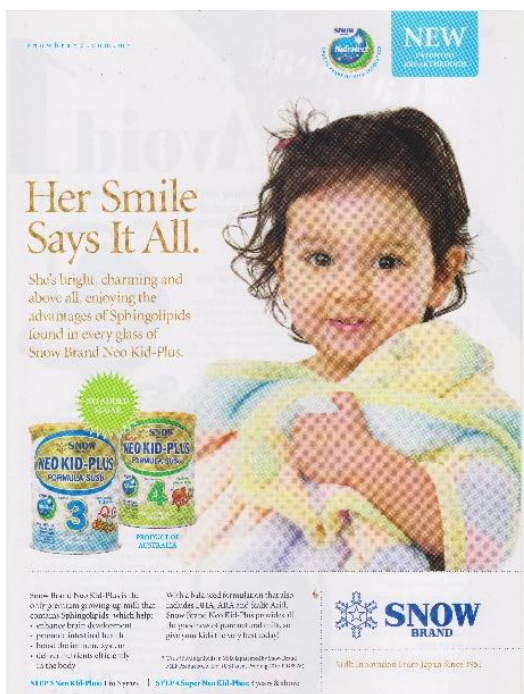

Advertisement 3 


\section{CONCLUSION}

In conclusion, it can be said that all the nine moves as presented in Kathpalia's (1992) framework were applicable to milk formula advertisements. The analytical framework by Bhatia (1993) and Kress and van Leeuwen $(1996,2006)$ were also relevant in tapping the communicative purposes and multimodal features used by advertisers in the milk formula advertisements. In order to competitively advertise the milk formula products, advertisers could perhaps take into consideration the moves and multimodal features highlighted in this chapter as they set the basis of communicating the purposes of producing milk formula advertisements.

\section{REFERENCES}

Acute Market Reports. 2015, May. Baby Food in Malaysia 2015. ERC. Retrieved on 8 December 2016 from http://www.acutemarketreports.com/report/baby-food-in-malaysia-2015.

Baker, P., Smith, J., Salmon, L., Friel, S., Kent, G., Lellamo, A., Dadhich, J. P. \& Refrew, M. J. 2016. Global Trends and Patterns of Commercial Milk-based Formula Sales: Is an Unprecedented Infant and Young Child Feeding Transition Underway? Public Health

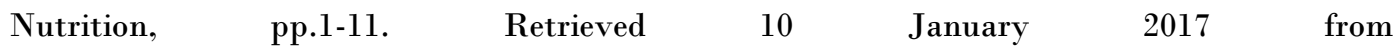
http://www2.hawaii.edu/ kent/GlobalFormulaTransition.pdf

Bawarshi, A. 2000. The Genre Function. College English. 62(3): 335-360.

Beane, K. 2013. Appealing to Women: An Analysis of Print Advertisements in Three Women's Interest Magazines. Elon Journal of Undergraduate Research in Communications. 4(2): 1-4. Retrieved from http:/www.studentpulse.com/articles/826/appealing-to-women-an-analysis-ofprint-advertisements-in-three-womens-interest-magazines.

Bhatia, V. 2014. Worlds of Written Discourse: A Genre-Based View. London and New York: Bloomsbury Academic.

Bhatia, V. K. 2004. Worlds of Written Discourse: A Genre-Based View. London: Continuum.

Bhatia, V. K. 1993. Analysing genre: Language Use in Professional Settings. London: Longman.

Canadean Market Research. 2015. Baby Food Market in Malaysia. Retrieved 7 December 2016 from www.canadean.com/.../baby-food-market-in-malaysia-valued-at-us\$443-million-in-2015.

Consterdine, G. 2005. How Magazine Advertising Works. Retrieved 10 August 2016 from https://www.magazinescanada.ca/uploads/File/files/general/HMAW-05.pdf.

Consterdine, G. 2009. Magazine Advertising Works! Seven Key Points. PPO: Periodical Publishers. $\begin{array}{lllll}\text { Retrieved } & 9 & \text { August } & 2016 & \text { from }\end{array}$ http://www.consterdine.com/articlefiles/78/ppai_adv_worksl.pdf.

Cook, G. 1992. The Discourse of Advertising. London: Routledge and Kegan Paul.

Foss, K. A. \& Southwell, B. G. 2006. Infant Feeding and the Media: The Relationship between Parents' Magazine Content and Breastfeeding, 1972-2000. International Breastfeeding Journal. $\begin{array}{llllll}\text { 1(10). } & \text { Retrieved } & 29 & \text { July } & 2015 & \text { from }\end{array}$ http://www.internationalbreastfeedingjournal.com/content/1/1/10.

Kathpalia, S. S. 1992. A Genre Analysis of Promotional Texts. Ph. D. Thesis. Singapore: National University of Singapore. 
Krasny, J. 2012. Every Parent Should Know the Scandalous History of Infant Formula. Retrieved from Business Insider website http://www.businessinsider.com/nestles-infant-formula-scandal-2012$6 ? \mathrm{IR}=\mathrm{T} \&$ op $=1$.

Kress, G. \& van Leeuwen, T. 1996. Reading Images: The Grammar of Visual Design. London: Routledge.

Kress, G. \& van Leeuwen, T. 2006. Reading Images: The Grammar of Visual Design. London: Routledge.

Meyers, D. 2001. Promoting and Supporting Breastfeeding. American Family Physician. 64(6): 931932. Retrieved from http://www.aafp.org/afp/2001/0915/p931.html.

Netshandama, V. O. 2002. Breastfeeding Practices of Working Women. Curationis. Retrieved 29 July 2015 from http://curationis.org.za/index.php/curationis/article/viewFile/698/636.

Onyechi, U. A. \& Nwabuzor, L. C. 2010. The Effect of Milk Formula Advertisement on Breast Feeding and Other Infant Feeding Practice in Lagos, Nigeria. Journal of Tropical Agriculture. Food, Environment and Extension. 9(3): 193-199.

Siu, C. W. \& Drummond, E. 2015. Opportunities in Infant Nutrition: Providing Our Most Precious Consumers Nutritious Products. Retrieved on 20 January 2017 from https://www.glanbianutritionals.com/sites/default/files/whitepaper/uploads/InfantNutrition_WhitePaper.pdf.

Suleiman, A. 2001. A Study of Marketing and Its Effect on Infant Feeding Practices. Med J Malaysia. 56(3), pp.319-323. Retrieved 1 June 2015 from http://www.emjm.org/2001/v56n3/Infant_Feeding_Practices.pdf.

The Nielsen Company. 2015. Oh, Baby! Trends in the Global Baby Food and Diapers Market: August 2015. Retrieved $11 \quad$ December $\quad 2016$ from http://www.nielsen.com/content/dam/nielsenglobal/de/docs/Nielsen\%20Global\%20Baby\%20Ca re\%20Report\%20-\%20August\%202015.pdf.

UNICEF. 2016. Adopting Optimal Feeding Practices is Fundamental to a Child's Survival, Growth and Development, But Too Few Children Benefit. Retrieved from http://data.unicef.org/topic/nutrition/infant-and-young-child-feeding/\#.

Wong, W. S. 2016, January 26. Ad expenditure for 2015 falls to RM13.6 billion. The Star. Retrieved 26 January 2017 from http://www.thestar.com.my/business/business-news/2016/01/26/adexpenditure-for-2015-falls-to-rml3dot6bil/. 